\title{
DEVELOPMENT OF THE ACCOUNTING PROFESSION ILLUSTRATED BY THE HISTORY OF RUSSIAN ACCOUNTING SOCIETIES
}

\author{
Svetlana N. Karelskaia \\ Saint Petersburg State University, Russia \\ Viatcheslav Y. Sokolov \\ Saint Petersburg State University of Economics, Russia \\ PricewaterhouseCoopers, Russia \\ Ekaterina I. Zuga \\ Saint Petersburg State University, Russia
}

\begin{abstract}
An analysis of the background of Professional Accountants' movement in Russia is necessary not only to understand the current state of Accounting Profession in this country in the environment of a free market albeit still developing market. It is also useful for studying the global regulation of our profession. This paper examines reasons underlying the current situation and draws conclusions as to what measures should be taken in Russia and other countries with similar business and social environment to effectively reform the Profession. The analysis of the history of Accountants' Professional movement in Russia makes us believe that when reforms are carried out in a professional field, it is important to consider the self-identity of professionals. The lack of developed civil institutions slows down the development of any profession. Professional organisations can achieve success only when they are established by and work together with relevant government authorities. Therefore, Russia and other similar economies would benefit from a mixed regulation of the Accounting Profession, like the existing in France, while the English accounting model seems less effective.
\end{abstract}

Keywords: profession, accountant, society

JEL code: M410 Accounting

\section{Introduction}

The Accounting Profession is currently non exist in Russia - one may only talk about the evolvement and initial steps of the Auditing Profession, which has historically found itself to be isolated from the Accounting profession. As of today, almost all accountants in Russia work as employed persons; independent accounting services are provided by individual firms, generally by audit firms, however their activities stay within the limits of small business. Accountants' activities are regulated by the government, and this regulation is limited to establishment of qualification requirements for the Chief Accountants of public interest companies, such as banks, insurance companies and public issuers of securities, while professional societies regulating the Accounting Profession has been formed as of today.

Efforts to set up such societies were made in Russia starting from the late $19^{\text {th }}$ century; however, all such efforts invariably failed. This paper analyses the reasons of the professional movement's failures with a view to developing an optimal approach to its establishment based on due consideration of its historic and cultural peculiarities and their proper analysis.

According to the research of recent publications on the history of accounting held by J. R. Edwards, the amount of papers on the development of the profession comes third after those on corporate accounting and cost and management accounting (Edwards, 2009, p. 51). However, comprehensive review of this area conducted by C. Poullaos, indicates that these publications 
regard the history of the profession only as the history in the United States, England and the Commonwealth countries. Only few authors touch upon the Continental Europe history. C. Poullaos researched the history of professional societies in Greece, France, Belgium, Spain. Last year C. Coronella, M. Sargiacomo and S. P. Walker published their paper, Portugal and Czechoslovakia (Poullaos, 2009, pp. 264-265). "Unification and Dual Closure in the Italian Accountancy Profession, 1861-1906" that deals with the history of professional societies in Italy. The authors also pay attention to the fact that the scope of research on the development of accounting profession in Europe is limited (Coronella, Sargiacomo, Walker, 2015, p. 167168). Also S. Walker published a paper on the role of women in development of accounting profession in England and Wales at the turn of the $20^{\text {th }}$ century (Walker, 2011).

Analysis of the Russian Accounting Profession, which was conducted according to UNCTAD methodology, has found that the Russian accounting practice basically follows the current trends. According to this study, Russia is highly rated as regards such corporate reporting infrastructure elements as financial reporting and audit statutory regulation systems. The study has found a full compliance with this component's performance benchmarks as regards such issues as statutory provision of authorisation to conduct audit activities and the professional ethics of accountants and auditors. At the same time, the study has found inadequate potential for regulation of investigations into misstatement of corporate reports and auditors' activities, as well as enforcement actions in the event of infringement of the existing rules related to such reports.

However, the level of human resources support of the corporate reporting-related processes was rated as low as $79 \%$. At the same time, there is a full compliance as regards accountants' and auditors' professional qualification and general education level, assessment of their professional skills and qualities, requirements relating to their practical experience and continuous professional development. It emerged that significantly worse figures describe the professional level of education and training of accountants and auditors, as well as their general qualification level. It all goes to show that nothing else but underdevelopment of the professional organisations represents the main problem of accounting development at the moment ${ }^{1}$.

This study was undertaken with a view to find an approach to the development of professional accounting organisations relevant for the country. The following methods were used in the study: the historical method, the systemic structural descriptive method, the comparativehistorical method and the historical typological method. For the purpose of systematisation of professional societies, the multi-criteria classification method was used. Application of the above-mentioned methods, as well as analysis of extensive factual materials devoted to the activities of Accountants' professional societies, have made it possible to ensure objectivity of the lessons learned and the results obtained.

\section{Historic experience of the main types of Russian accounting societies}

Accounting associations in Russia focused on three areas. First "academic" societies discussed the accounting methodology and disseminated their own ideas believing that ultimately, only ideas are of importance because both - status of profession and possibility to regulate it - represent the implementation of one or another accounting theory that should be primarily developed by accountants. The second ones "trade union" aimed at ensuring the profession's corporate interests: ensuring high salaries, social status, protection from claims or prosecution in the court, etc. Various trade unions were established to meet these goals. The

\footnotetext{
${ }^{1}$ UNCTAD-ISAR Accounting Development Tool: Russian Federation, Leonid Shneydman, The Ministry of Finance of the Russian Federation http://unctad.org/meetings/en/Presentation/ciiisar30_711_1LShneydman_en.pdf
} 
third "Professional" societies insisted that the first two tasks are interrelated. It is impossible to achieve the profession's high social status without its regulation by representatives of the profession. They know theory and practice that are beyond the reach of dilettantes; they maintain high ethical principles that prevent them from applying unworthy methods to maintain high public status, their honest and faithful approach to performing their professional obligations protects the rights of the society they serve to. It is faithful serve of the professionals that is able to place the community value to the accounting profession they serve to; ensure a high position in society and welfare. The main characteristics of the most important representatives of these three types of societies are summarized in the Appendices $1-3$.

\section{Analysis of society's activities}

Analysis of the data characterizing the societies shows that despite the differences in the goals that they set, all the societies had predominantly research (academic) nature. Even those societies that positioned themselves as trade union societies did not established the selfregulation of profession, limiting to its popularization, magazines publishing, and dissemination of best practices. This situation is mainly due to the absence of the accounting profession itself. The main reason is that all accountants in Russia have always worked as employed persons, while the majority of them and almost all of the leaders of the grassroots movement worked as civil servants and held a rank. In such circumstances, accountants constituted not a profession, but rather a group of persons united as an interest group or a club - it is not a mere coincidence that nothing else but a club has proved to be the most durable and smooth-running association of accountants.

In general, this situation matches the structure and the culture of the Russian society very accurately. In Russia, all institutions (not excepting professional ones) are formed from the top down and their establishment is impossible without any government support. Neither the professional environment nor business demonstrates any willingness to put together and keep up any professional institutions independent of the government. Business seeks to find competitive advantages in dependence of the government, deriving them from closeness to representatives of the authorities. Such approach promotes to the leadership of the professional movement not representatives of the profession, but rather academicians and professors, who, being civil servants in Russia as they are, constitute some kind of a communication bridge between business and the authorities. Features of accounting education in Russia contribute to the academic influence. They were marked by UNCTAD "the key features of accounting education included academicism, unitarianism and authoritarianism. Academicism implied that students should have studied a number of important disciplines in order to broaden their minds. Unitarianism intended to consolidate the educational process and the contents of all disciplines throughout the country. Authoritarianism meant that the educational process is fully subordinated to the authority of the teacher" (UNCTAD, 2014, p. 155).

Historical analysis shows that the methods of formation of the profession in different countries depended on the political and economic system, the legal system, the taxation system, the corporate reporting system, the accounting profession, and religion (Roberts et al., 2008). The two existing types of formation of the profession are determined by the type of legal system in place: from the bottom - self-regulation and from the top - state regulation. State regulation is applied in Roman codified law $^{2}$ countries and self-regulation - in the

\footnotetext{
${ }^{2}$ Code law was the dominant today in most of Europe (including Western Europe and Russia, in all of central and south America, in parts of Asia and Africa, Japan and even in some discrete areas of the common law world (e.g., Louisiana, Quebec, and Puerto Rico) (Apple, Deyling, 1995).
} 
common law countries ${ }^{3}$. Although Greece, Japan, and Bulgaria are classified as code law countries, they adopt similar professional practices to the USA accounting profession. This situation reflects the impact of politics and history on the accounting profession (Altintas, Yilmaz, 2012, p. 949). Since the second half of the $20^{\text {th }}$ century a third model appeared in the professional regulation - a mixed regulation, which involves the creation of professional institutions with the joint participation of the state and the accounting community. Such institutions have been successfully established in France. In 1957 Conseil National de la comptabilité (CNC) was formed, which included representatives of the accounting profession and the authorities. Already today under the influence of Public Companies accounting Oversight Board (PCOB) organization of French auditors Compagnie nationale des commissaires aux comptes, founded in 1969, was reorganized, and Haut Conseil du commissariat aux comptes (HSC), a joint body which composed of representatives of the profession, government, financial market regulators, the judiciary and academia, was established in its structure. Such increasing of self-regulation with "public participation" is currently becoming more and more widespread ${ }^{4}$.

Russia has also successfully applied the experience of mixed regulation for auditors. In the field of profession regulation according to the French model (with the participation of representatives of governmental institutions, the central bank, business and self-regulating associations of auditors) the Board for audit activities under the Ministry of Finance ${ }^{5}$ was established. Self-regulatory audit organizations in cooperation with the Ministry of Finance and the participation of leading universities formed a Unified certification commission for acceptance of qualification examination, involving entrance to the profession. Finally, the UNCTAD report noted as a positive moment in addition to the creation of a unified qualifying examination Coordination of the Ministry of Finance and the University on the example of the Financial University under the Government of the Russian Federation, where the research directors of departments are represented by the Minister of Finance, the Director of the Department of financial control, auditing, accounting and reporting, etc. This experience should be extended to other Universities (UNCTAD, 2014, p.176).

Consequently, success of professional societies is determined by the most efficient mix of representatives of the government, education and profession in the societies. Admittedly, as this model does not rely upon any widespread support on the part of professionals, all representatives of the accounting profession, it may not be sustainable and is completely dependent on the personal composition of the societies' management, whose interests this model reflects - all too often to the detriment of the profession.

\section{Conclusion}

This review of the history of Russian accounting societies has shown that, despite continued and multiple efforts, no genuinely professional organisation has ever evolved in Russia. Analysis of the objectives set by the Societies, their organisational structure, the terms and conditions of their membership, their line-up, and the nature of relations within their management teams explains the reasons thereof.

It is an interest in their trade, rather than a professional interest, that has always brought together all Russian accountants. On the other hand, business has always driven a wedge

\footnotetext{
3 These countries include UK, USA, Ireland, Australia, New Zealand, Malaysia, Pakistan, India, and South Africa (Mueller et al., 1997).

4 UNCTAD-ISAR Regulatory and institutional foundations for high-quality corporate reporting http://unctad.org/meetings/en/Presentation/ciiisar29_3110M_TatianaKrylova.pdf

${ }^{5}$ http://old.minfin.ru/en/accandaudit/index.php
} 
between them: above all things, all of the societies ended in financial failure. The second reason of their discontinued operations was a direct instruction given by the authorities.

Therefore, taking into consideration the historical peculiarities of the professional development in Russia, one may draw a conclusion that regulation of the profession should use a mixed, public-private, model. Within this model, professional societies would be developed on a fifty-fifty basis - on the basis of representation of the state and business. An advantage of this model is that it would not require any intermediary between business and the state, which would openly cooperate with each other on the basis of transparent rules. Such model would be able to develop the profession, eliminating the problems that have brought to destruction the societies created by our predecessors.

\section{References}

Alexander, D. (2013). The Soviet accounting bulletin, 1973-1983. Accounting and Management Information Systems, Vol. 12, no. 2.

Alexander, D., Nobes, C. (2010). Financial accounting: An international introduction. UK: Pearson Education Limited.

Altintas, N., Yilmaz, F. (2012). The Accounting Profession: A Descriptive Study of the Common and Code Law Countries. Journal of Modern Accounting and Auditing, July 2012, Vol. 8, No. 7, pp. 932-950.

Apple, J. G., Deyling, R. P. (1995). An example on the civil-law system. Washington DC: Federal Judicial Center.

Charter of the All Soviet Union Society for Supporting of Socialist Accounting. (1935). [(Устав Всесоюзного общества сочиалистического учета (ВОСУ) при ВЦСПС)]. Moscow: Publishing house VOSU. (in Russian)

Charter of the Moscow Accountants Society. (1908). [(Устав Московского общества бухгалтеров)]. Moscow: Publishing House of P. T. Saprykin. (in Russian)

Charter of the Russian Accounting Society for Mutual Assistance. (1907). [(Устав Русского счетоводного общества взаимной помощи)]. St Petersburg.

Charter of the Society for Dissemination of Commercial Knowledge. (1891). [(Устав Общества для распространения коммерческих знаний, утвержденный 20 июля 1889 года Министерством Финансов)]. St Petersburg: Printing house and lithography of A. E. Vineke.

"Charter of the Society of Bookkeepers, approved on June, 261892 and amended on March, 6 1903" (1908). Supplement to the Magazine "Practical Life”, (1/4). [(Устав Общества счетоводов, утвержденный 26 июня 1892 г. и измененный 6 марта 1903 г. // Приложение к журналу «Практическая жизнь»)].

Chronicle of Life of Business Accounting Department of the RTS (1923). Accounting. (1-3). [(Хроника жизни Отдела учета хозяйственной деятельности P.T.O // Счетоводство)]. (in Russian)

Coronella, C., Sargiacomo, M., Walker S. P. (2015). Unification and Dual Closure in the Italian Accountancy Profession, 1861-1906. European Accounting Review, vol. 24, no. 1, pp. 167-197.

Edwards, J. R. (2009). Subjects, sources and dissemination. In J. R. Edwards and S. P. Walker (Eds.), The Routledge companion to accounting history. London: Routledge. pp. 50-69.

Essay on activities of the Society for the Dissemination of Commercial Knowledge from 1889 to 1899. (1899). [(Очерк деятельности общества для распространения коммерческих 
знаний с 1889 по 1899 год)]. St Petersburg: Publishing house of the Stroitel magazine. (in Russian)

Leningrad Club of Accountants (1969). Accounting. (3). [(Клуб бухгалтеров в Ленинграде // Бухгалтерский учет)]. (in Russian)

Lvova, D. (2005). Professional Unification of Accountants: a history of the founding and activities. [(Львова Д. А. Профессиональные объединения бухгалтеров: история создания и деятельности.)]. Moscow: The Institute of Professional Accountants in Russia: informational agency IPBR-BINFA. (in Russian)

Mattessich, R. (2008). Two Hundred Years of Accounting Research. New York: Routledge.

Mueller, G. G., Gernon, G., Meek, G. K. (1997). Accounting: An international perspective. Irwin/McGraw Hill.

Novikov, A. (1923). Public undertakings of accountants. Accounting. (1-3). [(Новиков A. A. Общественные начинания счетоводов // Счетоводство)]. (in Russian)

Organisational Meeting of the Society Innovators Accounting. (1924). [(Организационное собрание объединения работников учета)]. Moscow: Publishing House "Gudok". (in Russian)

Poullaos, C. (2009). Professionalization. In J. R. Edwards, S. P. Walker (Eds.), The Routledge companion to accounting history. London: Routledge. pp. 247-273.

Ramirez, C. (2012). Reforme or Renaissance? France`s 1966 Companies Act and the problem of "professionalization" of the auditing profession in France. French Accounting History: New Contributions edited by Yves Levant, Olivier de la Villarmois. Routledge, Obingdon, Oxon.

Reports on Activities of the Society for the Dissemination of Commercial Knowledge for the period from 1895-1896, 1900-1901, 1902-1906, 1907-1915. (1896-1915). [(Отчет о деятельности Общества для распространения коммерческих знаний с 1895-1896, 19001901, 1902-1906, 1907-1915 гг.)]. St Petersburg. (in Russian)

Reports of the Society for the Russian Accounting Society for Mutual Assistance for the period from 1907-1908, 1908-1909,1909-1910,1910-1911, 1911-1912, 1913-1914, 19141915, 1915-1916. (1908-1916). [(Отчеты Русского Счетоводного Общества взаимной помощи за период 1907-1908, 1908-1909,1909-1910,1910-1911, 1911-1912, 19131914,1914-1915, 1915-1916)]. St. Petersburg. (in Russian)

Reports on Activities of the Society of Bookkeepers from 1897, 1898, 1899, 1900, 1902, 1904. (1898-1905). [(Отчет о деятельности Общества счетоводов с 1897, 1898, 1899, 1900, 1902, 1904 гг.)]. St. Petersburg. (in Russian)

Roberts, C., Weetman, P., Gordon, P. (2008). International corporate reporting: A comparative approach. UK: Pearson Education Limited.

Rough Draft of the Institute of Accountants (1896, 1897). Accounting. (19-20; 2). [(Предварительный проект Института бухгалтеров // Счетоводство)]. (in Russian)

Russian Press. (1904). Practical Life. (23). [(Русская пресса// Практическая жизнь)]. (in Russian)

Sokolov, Y. V. (1991). An outline of the history of accounting. [(Соколов Я. В. Очерки по истории бухгалтерского учета.)]. Moscow: Finance and Statistics. (in Russian) 
Sokolov, V. (2015). A History of professional accounting societies in societies in St. Petersburg. Accounting History, Vol. 20, no. 3, p. 375-395.

Sokolov, V., Karelskaya, S. (2014). The First Attempt to Create a Professional Accountants' Organization in Russia. In: International Conference on Accounting, Auditing, and Taxation (ICAAT 2014), pp. 304-315.

The Institute of Professional Accountants in Russia (IPBR) offers new types of training and diplomas. Interview with O. M. Ostrovsky. (2011). Bulletin of Professional Accountant. (1). [(ИПБ России предлагает новые виды обучения и аттестатов. Интервью с О. М. Островским // Вестник профессиональных бухгалтеров)]. (in Russian)

UNCTAD Report by the secretariat of the United Nations Conference on Trade and Development (2014). New York and Geneva.

Waldenberg, E. (1890). On preventing women from entering the Society for the Dissemination of Commercial Knowledge. [(Вальденберг Э. Г. По поводу недопущения женщин в члены Общества для распространения коммерческих знаний)]. St. Petersburg: Commercial publishing house E. Tile. (in Russian)

Walker, S. P. (2011). Professions and patriarchy revisited. Accountancy in England and Wales,1887-1914, Accounting History Review, vol. 21, no. 2, pp. 185-225.

What accountant needs to know about ORU. (1925). [(Что нужно знать счет работнику об ОРУ)]. Moscow: Publishing house under the name of Artem "Latizdat". (in Russian)

Zuga, E. (2010). Russian Triple Accounting System and Fyodor Ezersky. In: 2nd Balkans and Middle East Countries Conference on Accounting and Accounting History (2.BMAC). September 15-18, 2010. Istanbul. Turkey. Conference Proceedings, pp. 1791-1797. 
Appendix 1

Academic Societies

\begin{tabular}{|c|c|c|c|c|c|c|}
\hline $\begin{array}{l}\text { Name of } \\
\text { Societies, } \\
\text { their } \\
\text { founders } \\
\text { and } \\
\text { location }\end{array}$ & $\begin{array}{l}\text { Society for the } \\
\text { Dissemination of } \\
\text { Commercial } \\
\text { Knowledge } \\
\text { E. Waldenberg, St. } \\
\text { Petersburg } \\
1889-1917\end{array}$ & $\begin{array}{l}\text { Society of } \\
\text { Bookkeepers } \\
\text { F. Ezersky, } \\
\text { Moscow 1892- } \\
1916\end{array}$ & $\begin{array}{l}\text { Moscow } \\
\text { Accountants } \\
\text { Society, F. Belmer, } \\
\text { V. Brunner, A. } \\
\text { Gulyayev, } \\
\text { Moscow, 1907- } \\
1913\end{array}$ & $\begin{array}{l}\text { Russian } \\
\text { Accounting } \\
\text { Society for Mutual } \\
\text { Assistance } \\
\text { E. Sivers, St. } \\
\text { Petersburg } \\
1908-1916\end{array}$ & $\begin{array}{l}\text { Accounting } \\
\text { Department of the } \\
\text { Russian Technical } \\
\text { Society, A. } \\
\text { Novikov, Moscow, } \\
\text { 1923-1925 }\end{array}$ & $\begin{array}{l}\text { Leningrad Club of } \\
\text { accountants, V. } \\
\text { D.Sokolov, } \\
\text { St. Petersburg, } \\
\text { 1946-1986 }\end{array}$ \\
\hline Goal & $\begin{array}{l}\text { 1. To facilitate } \\
\text { dissemination of } \\
\text { theoretical and } \\
\text { practical commercial } \\
\text { knowledge. } \\
\text { 2. To bring together } \\
\text { individuals in order to } \\
\text { encourage their further } \\
\text { development through } \\
\text { finding an } \\
\text { employment for them }\end{array}$ & $\begin{array}{l}\text { 1. To provide a } \\
\text { forum for } \\
\text { accountants and } \\
\text { businessmen for } \\
\text { facilitate } \\
\text { comprehensive } \\
\text { research in the } \\
\text { economics field. } \\
2 \text { To assist with } \\
\text { their employment } \\
\text { as well as to } \\
\text { organize joint } \\
\text { leisure activities for } \\
\text { the Society } \\
\text { members and their } \\
\text { families }\end{array}$ & $\begin{array}{l}\text { 1. To bring } \\
\text { together Society } \\
\text { members in order } \\
\text { to enable them to } \\
\text { share knowledge } \\
\text { in accounting, } \\
\text { commercial and } \\
\text { financial sciences. } \\
2 . \text { To assist } \\
\text { Society members } \\
\text { and their families } \\
\text { with employment } \\
\text { and in other } \\
\text { spheres }\end{array}$ & $\begin{array}{l}\text { 1. To develop and } \\
\text { spread theoretical } \\
\text { and practical } \\
\text { knowledge of } \\
\text { commerce. } \\
\text { 2. To help Society } \\
\text { members find } \\
\text { employment and to } \\
\text { finance aid for } \\
\text { their families }\end{array}$ & $\begin{array}{l}\text { 1. To establish a } \\
\text { close relationship } \\
\text { between } \\
\text { engineering and } \\
\text { economics. } \\
\text { 2. To study the } \\
\text { activities of } \\
\text { government and } \\
\text { public bodies and } \\
\text { private entities }\end{array}$ & $\begin{array}{l}\text { 1. To disseminate } \\
\text { theoretical and } \\
\text { practical } \\
\text { accounting } \\
\text { knowledge. } \\
\text { 2. To share best } \\
\text { accounting practice }\end{array}$ \\
\hline $\begin{array}{l}\text { Member- } \\
\text { ship }\end{array}$ & $\begin{array}{l}\text { Honorary members } \\
\text { exempt from fees, } \\
\text { fellows }-12 \text { rubles } \\
\text { annually or } 120 \text { for } \\
\text { life, candidates and } \\
\text { correspondent } \\
\text { members } 20 \text { or } 200 \\
\text { rubles respectively } \\
\text { Membership could be } \\
\text { awarded Joining fee } \\
\text { was } 3 \text { rubles }\end{array}$ & $\begin{array}{l}\text { Fellows and } \\
\text { candidates a lump } \\
\text { sum of } 20 \text { rubles } \\
\text { and an annual fee } \\
\text { of } 12 \text { rubles, } \\
\text { life members }- \text { a } \\
\text { lump sum of } 200 \\
\text { rubles, certified } \\
\text { accountants a lump } \\
\text { sum of } 300 \text { rubles }\end{array}$ & $\begin{array}{l}\text { Honorary members } \\
\text { exempt from fees } \\
\text { Fellows annually: } \\
\text { - accountants - } 3 \\
\text { rubles, } \\
\text { - expert } \\
\text { accountants- } 5 \\
\text { rubles } \\
\text { - candidates }-1.5 \\
\text { rubles } \\
\text { Joining fee was } 25 \\
\text { rubles }\end{array}$ & $\begin{array}{l}\text { Fellows- } 12 \text { rubles } \\
\text { annually Associate } \\
-8 \text { annually } \\
\text { Life members }- \text { a } \\
\text { lump sum of } 325 \\
\text { rubles made in two } \\
\text { instalments }(200+ \\
125)\end{array}$ & $\begin{array}{l}\text { Fellows }-10 \text { rubles } \\
\text { annually, or } 100 \\
\text { for life } \\
\text { Candidates }-20 \\
\text { rubles. annually, or } \\
200 \text { for life } \\
\text { Joining fee was } 10 \\
\text { rubles }\end{array}$ & $\begin{array}{l}\text { No fees, } \\
\text { Only board was } \\
\text { elected for all } \\
\text { others - free } \\
\text { participation }\end{array}$ \\
\hline $\begin{array}{l}\text { Women`s } \\
\text { member- } \\
\text { ship }\end{array}$ & Impossible & Impossible & Allowed & Allowed & Allowed & $\begin{array}{l}\text { Allowed, majority } \\
\text { of members }\end{array}$ \\
\hline $\begin{array}{l}\text { Causes } \\
\text { and } \\
\text { conditions } \\
\text { of } \\
\text { expulsion } \\
\text { from the } \\
\text { Society }\end{array}$ & $\begin{array}{l}\text { For violation of the } \\
\text { Charter and Rules set } \\
\text { by the Society. } \\
\text { For behavior } \\
\text { incompatible with the } \\
\text { Society's standing. } \\
\text { The decisions on } \\
\text { expulsion were taken } \\
\text { by the Society's } \\
\text { general meeting }\end{array}$ & $\begin{array}{l}\text { For promoting } \\
\text { himself as a } \\
\text { member of the } \\
\text { Society at private } \\
\text { or judicial } \\
\text { organizations with } \\
\text { the aim of getting } \\
\text { expert reviews, for } \\
\text { violation of } \\
\text { privileged } \\
\text { information policy, } \\
\text { and for behavior } \\
\text { incompatible with } \\
\text { an expert's } \\
\text { standing, for failure } \\
\text { to repay a loan, } \\
\text { failure to pay } \\
\text { gambling debts } \\
\text { within a week from } \\
\text { the date of a second } \\
\text { entry made in the } \\
\text { debt book }\end{array}$ & $\begin{array}{l}\text { For substantially } \\
\text { proven negligence } \\
\text { while in the } \\
\text { employment of } \\
\text { commercial or } \\
\text { public } \\
\text { organizations } \\
\text { based on a } \\
\text { complaint, or for } \\
\text { malevolent } \\
\text { behavior, by an } \\
\text { absolute majority } \\
\text { vote of the general } \\
\text { meeting. } \\
\text { For failure to pay } \\
\text { membership fees } \\
\text { during a year }\end{array}$ & Not defined & $\begin{array}{l}\text { For clear violation } \\
\text { of the Charter and } \\
\text { the rules set by the } \\
\text { Society, and } \\
\text { generally for } \\
\text { behavior } \\
\text { incompatible with } \\
\text { the Society's } \\
\text { standing. } \\
\text { For failure to pay } \\
\text { membership fee for } \\
\text { four months }\end{array}$ & Not defined \\
\hline
\end{tabular}




\begin{tabular}{|c|c|c|c|c|c|c|}
\hline $\begin{array}{l}\text { Society } \\
\text { structure }\end{array}$ & $\begin{array}{l}\text { Discussion and } \\
\text { Information Division, } \\
\text { Library, Intermediary } \\
\text { Committee, } \\
\text { Educational Division, } \\
\text { Teachers' Conference, } \\
\text { Committee of the } \\
\text { Fund for Lower- } \\
\text { Income Accountants, } \\
\text { their widows and } \\
\text { orphans }\end{array}$ & Not determined & $\begin{array}{l}\text { Academic } \\
\text { Department, } \\
\text { Library, } \\
\text { Accounting } \\
\text { bureau, Mutual aid } \\
\text { fund, } \\
\text { Organising } \\
\text { Committee for the } \\
\text { 1st All-Russian } \\
\text { Convention of } \\
\text { Accountants }\end{array}$ & $\begin{array}{l}\text { Accounting } \\
\text { Department, } \\
\text { Loan and Savings } \\
\text { Department, } \\
\text { Department of } \\
\text { Responsible } \\
\text { Bookkeepers, } \\
\text { Educational } \\
\text { Department, } \\
\text { Academic } \\
\text { Department, } \\
\text { Administrative } \\
\text { Department }\end{array}$ & $\begin{array}{l}\text { Two sections: } \\
\text { statisticians and } \\
\text { economists; } \\
\text { accountants } \\
\text { (accounting } \\
\text { matters: general } \\
\text { theory and } \\
\text { practice, trade and } \\
\text { industry } \\
\text { enterprises, } \\
\text { transport } \\
\text { companies, } \\
\text { publicly-funded } \\
\text { organizations, } \\
\text { accounting expert } \\
\text { review and control, } \\
\text { taxes) }\end{array}$ & $\begin{array}{l}\text { Board } \\
\text { Monthly meetings }\end{array}$ \\
\hline $\begin{array}{l}\text { Presence } \\
\text { in print } \\
\text { (years of } \\
\text { public } \\
\text { cation) }\end{array}$ & $\begin{array}{l}\text { Magazine } \\
\text { "Schetovodstvo" } \\
\text { (Accounting) (1889- } \\
1902 \text { ) }\end{array}$ & $\begin{array}{l}\text { Magazine } \\
\text { "Practicheskaya } \\
\text { zhizn" (Practical } \\
\text { Life) (1889-1914), } \\
\text { "Zhurnal } \\
\text { Obschestva } \\
\text { schetovodov" } \\
\text { (Magazine of the } \\
\text { Society of } \\
\text { Bookkeepers) } \\
\text { (1896-1905), } \\
\text { Magazine } \\
\text { "Schetovod" } \\
\text { (Bookkeeper) } \\
\text { (1889, (1911-1914) }\end{array}$ & $\begin{array}{l}\text { Magazine "Bulleten } \\
\text { Moscovskogo } \\
\text { obschestva } \\
\text { Buchgalterov" } \\
\text { (Bulletin of the } \\
\text { Moscow } \\
\text { Accountants } \\
\text { Society) (1908- } \\
\text { 1909) }\end{array}$ & $\begin{array}{l}\text { Magazine } \\
\text { "Kommer- } \\
\text { cheskoeobrazovani } \\
\text { e" (Commercial } \\
\text { Education) } \\
(1908-1916)\end{array}$ & $\begin{array}{l}\text { Magazine } \\
\text { "Schetovodstvo" } \\
\text { (Accounting) } \\
(1923-1930)\end{array}$ & $\begin{array}{l}\text { No own magazine } \\
\text { but regular } \\
\text { contribution to } \\
\text { "Bukhgalterskiy } \\
\text { uchet" } \\
\text { (Accounting) (1938 } \\
\text { till present), The } \\
\text { Soviet accounting } \\
\text { bulletin (1973- } \\
\text { 1983) (UK, } \\
\text { Birmingham) }\end{array}$ \\
\hline
\end{tabular}


Trade Union Societies

Appendix 2.

\begin{tabular}{|c|c|c|c|}
\hline $\begin{array}{l}\text { Names of } \\
\text { Societies, } \\
\text { their } \\
\text { founders } \\
\text { and location }\end{array}$ & $\begin{array}{l}\text { Artel of Bookkeepers } \\
\text { F. Ezersky, A. Rogov, G. } \\
\text { Bukeshin, } \\
\text { Moscow, 1887-? }\end{array}$ & $\begin{array}{l}\text { Society of Accounting Employees } \\
\text { Moscow 1924-1931 }\end{array}$ & $\begin{array}{l}\text { All-Soviet Union Society for Supporting Socialist } \\
\text { Accounting } \\
\text { Moscow, 1931-1936 }\end{array}$ \\
\hline Goal & $\begin{array}{l}\text { 1. To assist with filling } \\
\text { vacancies at various } \\
\text { companies for accountants, } \\
\text { bookkeepers and clerks. } \\
2 . \text { To provide specialists for } \\
\text { organizing the accounting } \\
\text { system, checking and } \\
\text { straightening the books and } \\
\text { drafting reports }\end{array}$ & $\begin{array}{l}\text { 1. To assist the Soviet Government and the } \\
\text { Russian Communist Party in establishing } \\
\text { and improving proper accounting, } \\
\text { calculations and control in all spheres of } \\
\text { national economy and administration }\end{array}$ & $\begin{array}{l}\text { 1. To struggle for an "all-people's all- } \\
\text { encompassing universal" (Lenin) socialist } \\
\text { accounting and control and involving the popular } \\
\text { masses of workers and labourers in practical work } \\
\text { in this area }\end{array}$ \\
\hline Membership & $\begin{array}{l}\text { Joining fee of } 330 \text { rubles. } \\
\text { Furthermore, the Artel } \\
\text { general meeting could } \\
\text { decide to charge monthly } \\
\text { contributions to cover its } \\
\text { current expenses }\end{array}$ & $\begin{array}{l}\text { Only trade union members could join the } \\
\text { Society: } \\
\text { 1) practical accountants with at least five } \\
\text { years of experience; } \\
\text { 2) researchers of accounting; } \\
\text { 3) teachers of bookkeeping and } \\
\text { accounting; } \\
\text { 4) responsible workers of professional } \\
\text { bodies involved in the union's economy. } \\
\text { Monthly membership fees: for those whose } \\
\text { income did not exceed } 150 \text { rubles - } \\
25 \text { kopecks, up to } 200 \text { rubles - } 50 \text { kopecks, } \\
\text { up to } 250 \text { rubles - } 1 \text { ruble; Joining fees - } \\
50 \text { kopecks. The unemployed were exempt } \\
\text { from membership fees }\end{array}$ & $\begin{array}{l}\text { The Society consisted of both individuals and } \\
\text { legal entities. } \\
\text { Regardless of their occupation: accountants, } \\
\text { milkmaid sorturners. } \\
\text { Monthly membership fees for individuals (from } \\
15 \text { to } 25 \text { kopecks) and legal entities (from } 5 \text { to } \\
200 \text { roubles). Joining fees were equal to a } \\
\text { monthly membership fee }\end{array}$ \\
\hline $\begin{array}{l}\text { Women`s } \\
\text { membership }\end{array}$ & Impossible & Allowed & Allowed \\
\hline $\begin{array}{l}\text { Causes and } \\
\text { conditions } \\
\text { of expulsion } \\
\text { from the } \\
\text { Society }\end{array}$ & $\begin{array}{l}\text { Suspension from the artel or } \\
\text { a cash penalty, not more } \\
\text { than six months' } \\
\text { remuneration, for violation } \\
\text { of the charter or instructions } \\
\text { made by the general } \\
\text { meeting, for inappropriate } \\
\text { behavior or failure to do } \\
\text { their work properly }\end{array}$ & $\begin{array}{l}\text { Relocation outside of the Society's area of } \\
\text { operation. } \\
\text { Failure to pay membership fees for three } \\
\text { months. } \\
\text { Maintaining evident passiveness (regular } \\
\text { failures to participate in the meetings of } \\
\text { sections, groups, etc.). } \\
\text { Committing criminal offences sentenced } \\
\text { by court. } \\
\text { Malignant and regular violation of } \\
\text { professional ethics. } \\
\text { Withdrawal from the Trade Union }\end{array}$ & $\begin{array}{l}\text { Wrongdoings and actions leading to expulsion } \\
\text { from the trade union, collective farm, commune } \\
\text { or production cooperative for the disabled. } \\
\text { Regular failures to perform the Society's } \\
\text { assignments and violations of the Charter. The } \\
\text { decisions to expel individuals from the Society } \\
\text { were taken by a low-level group of the Society's } \\
\text { cell, subject to approval by the respective Section } \\
\text { Bureau; decisions to expel legal entities were } \\
\text { made by respective Sections }\end{array}$ \\
\hline $\begin{array}{l}\text { Society } \\
\text { structure }\end{array}$ & Not determined & $\begin{array}{l}\text { Administrative and Propaganda } \\
\text { Department } \\
\text { Consultation and Expert Review } \\
\text { Department Academic council } \\
\text { Editing and Publishing Department }\end{array}$ & $\begin{array}{l}\text { The supreme body was the All-Union } \\
\text { Convention. } \\
\text { The highest executive body was the Central } \\
\text { Bureau (Plenary meeting) / President of the } \\
\text { Central Bureau. } \\
\text { Republican, regional and district offices / Bureaus } \\
\text { of republican, regional and district offices. } \\
\text { Cells / Cell bureaus - Accounting and control } \\
\text { stations within the cell / Heads of cell accounting } \\
\text { and control stations. } \\
\text { Low-level groups - Accounting and control } \\
\text { stations within the group / Heads of group } \\
\text { accounting and control stations }\end{array}$ \\
\hline $\begin{array}{l}\text { Presence in } \\
\text { print (years } \\
\text { of } \\
\text { publication) }\end{array}$ & No own magazine & $\begin{array}{l}\text { Magazine "Schetnaya mysl” (Accounting } \\
\text { Idea) (1925-1930), Magazine } \\
\text { "Schetovodstvo" (Accounting) (1923- } \\
\text { 1930) }\end{array}$ & $\begin{array}{l}\text { Magazine“Za socialisticheskiy uchet” (For } \\
\text { Socialist Accounting) (1930-1932) }\end{array}$ \\
\hline
\end{tabular}


Appendix 3

\section{Professional Societies}

\begin{tabular}{|c|c|}
\hline $\begin{array}{l}\text { Name of } \\
\text { Societies }\end{array}$ & $\begin{array}{l}\text { The Institute of Professional Accountants in Russia } \\
\text { 1997till present }\end{array}$ \\
\hline Goal & $\begin{array}{l}\text { 1. To assist the members in developing professional rules and standards, creating the legal } \\
\text { regulatory framework for accounting, audit and financial management. } \\
\text { 2. To develop the accounting and auditing professions. } \\
\text { 3. To represent and defend the rights and legal interests of the members, assist them in } \\
\text { defending their professional interests. }\end{array}$ \\
\hline Membership & $\begin{array}{l}\text { Both individuals and legal entities could join the Institute. The following types of membership } \\
\text { were available: fellow candidate, fellow, corporate member, honorary member. } \\
\text { Honorary members are exempt from fees. Fellow - annually } 1,000 \text { to } 3,600 \text { rubles based on } \\
\text { corporate member joining fee }-3,000 \text { rubles, } 3,000 \text { rubles for each individual who is a member } \\
\text { of the foreign legal entity, annual membership fee } 28,000 \text { rubles, } 900 \text { rubles for each individual } \\
\text { who is a member of a foreign legal entity }\end{array}$ \\
\hline $\begin{array}{l}\text { Women`s } \\
\text { membership }\end{array}$ & Allowed \\
\hline $\begin{array}{l}\text { Causes and } \\
\text { conditions of } \\
\text { expulsion from } \\
\text { the Society }\end{array}$ & $\begin{array}{l}\text { For failure of an Institute member to perform their duties, to comply with the Charter, the } \\
\text { Provisions on membership in the Institute of Professional Accountants and Auditors in Russia, } \\
\text { and with the Code of Ethics for professional accountants and auditors who are members of the } \\
\text { Institute of Professional Accountants in Russia. If false information is discovered in the } \\
\text { documents presented for admission to the Institute.For deliberate actions hampering the } \\
\text { achievement of the Institute's goals (if proven with documents). }\end{array}$ \\
\hline $\begin{array}{l}\text { Society } \\
\text { structure }\end{array}$ & $\begin{array}{l}\text { Committees: } \\
\text { 1. Membership and professional ethics. } \\
\text { 2. Professional education. } \\
\text { 3. Innovative education policy. } \\
\text { 4. Accounting and taxation in commercial organizations. } \\
\text { 5. For accounting at public organizations. } \\
\text { 6. Taxation at commercial and not-for-profit and public organizations. } \\
\text { 7. Regional policy and collaboration with the divisions of the Institute of Professional } \\
\text { Accountants in Russia. } \\
\text { 8. Foreign relations. } \\
\text { 9. IFRS. } \\
\text { 10. Budgeting Commission. } \\
\text { 11. Expert panels. }\end{array}$ \\
\hline $\begin{array}{l}\text { Presence in } \\
\text { print } \\
\text { (years of } \\
\text { publication) }\end{array}$ & $\begin{array}{l}\text { Magazine "Vestnik Professionalnykh Bukhgalterov" (Bulletin of Professional Accountant) } \\
\text { (2011 till present) } \\
\text { Magazine "Vestnik Bukhgaltera Moskovskogo Regiona" (Bulleting of Moscow`s Accountant) } \\
\text { (2009 till present) }\end{array}$ \\
\hline
\end{tabular}

